\title{
11
}

\section{Multi-level Governance in Integrated Land Use and Natural Resource Planning on the Urban Fringe: A Case Study of Processes and Structures for Governing across Boundaries}

\author{
Iris Iwanicki, Kathryn Bellette and Stephen Smith
}

\section{Introduction}

The southern and eastern rural-urban fringe of metropolitan Adelaide provides a case study of different governance systems across three levels of government - federal, state and local - dealing with urban development and water resources management. As Kay observes in his chapter, multilevel governance (MLG), while over 20 years old, is a relatively little acknowledged process 'creating cross-jurisdictional policy capacity in Australia, across and between different governance jurisdictions to match the territorial scale that is functional for effective policy response'. The subject of this chapter provides a demonstration that the MLG concept (see also Hooghe and Marks 2001) can contribute to outcomes involving land-use planning, natural resource management and different levels of governance structured around water management. This MLG case study is of formal, institutionalised MLG with a hierarchy of governance 
determined by legislation. The MLG is horizontal between state government portfolios and amongst local governments, vertical between state government and local government, and ultimately driven by water reforms required by the federal government. Interwoven governance frameworks in this case study shifted over two decades during the 1990s and 2000s, and required simultaneous consideration of numerous and varied interests.

During this period, legislative, governance structures and geographical boundaries changed, primarily through implementation of the South Australian Water Resources Act (SA) 1997. The ability to integrate across the planning processes outlined in the Water Resources Act and the South Australian Development Act 1993 was an opportunity for the implementation of consistent policy across the three levels of governance responsible for development and water resources management. Integration also involved optimising benefits and costs for the many different parties to arrive at an agreed outcome.

This chapter is structured in three sections. The first describes the role of one of the five local councils within the southern region in facilitating integration of natural resource management (NRM) and urban development in the Willunga Basin within the case study area. The Willunga Basin is a geographic area that, at the time, lay partly within four council areas. ${ }^{1}$ The second section outlines how the concept was progressed at the catchment level by the Onkaparinga Catchment Water Management Board. Legislation, policies and governing the management of water-resource sustainability and urban development are discussed as well as how the process involved broad levels of public, local and state government consultation and information exchange - driven by the desire to effectively integrate policies consistently across all governance levels. Third, lessons learnt from the processes are identified and discussed.

1 Namely, Willunga, Adelaide Hills, Noarlunga, Happy Valley, Yankalilla councils prior to amalgamation of the Willunga, Happy Valley and Onkaparinga councils in 1998. 


\section{Historical context - integrated planning of the Willunga Basin}

In the early 1990s, the southern-most metropolitan council, the District Council of Willunga (Willunga DC), incorporated small pockets of urban settlements within a predominantly rural area and coastal housing. McLaren Vale, renowned for its quality wines, was within the Willunga Basin, which also included magnificent coastal beaches and the Aldinga Scrub - the largest metropolitan remnant of historic coastal vegetation and plains bordered by the Willunga hills. It was close to city markets, despite high levels of unemployment compared to the rest of the metropolitan area. By the 1990s, vineyards had predominantly replaced the almond orchards of Willunga and the area was declared a water protection area due to concerns over the quantity and quality of groundwater in the basin. ${ }^{2}$

The council area's landscape of orchards, grain-growing and vineyards with small local wineries was viewed by the council and some sections of the community as an agricultural resource. It is bordered to the north by coastal housing, which is poised to expand in response to metropolitan population growth.

During the 1990s, the Willunga DC area increasingly came under pressure for urban development by land speculators, despite lacking social and physical infrastructure. Owners of crop lands, troubled by the impact of expanding suburban life and facing retirement, anticipated the sale of their land as a form of superannuation. The state viewed the Willunga council area as predominantly deferred urban in nature, with state population projections of 70,000 - an increase from 7,000 - through continued suburbanisation of the land. As a result, the community within the Willunga Basin was divided on future choices (Figure 11.1). ${ }^{3}$

2 SA Government Gazette, 24 December 1998; see also Iwanicki (1994, 1995).

3 The DC of Willunga and the South Australian Government signed a memorandum of understanding to jointly undertake a process of strategic planning to identify where urban development could occur. Funded by the federal Better Cities Program, the process included intensive community discussion, peer review by a reference group and regular council endorsement of each stage of the process (Iwanicki 1994, 1995). 


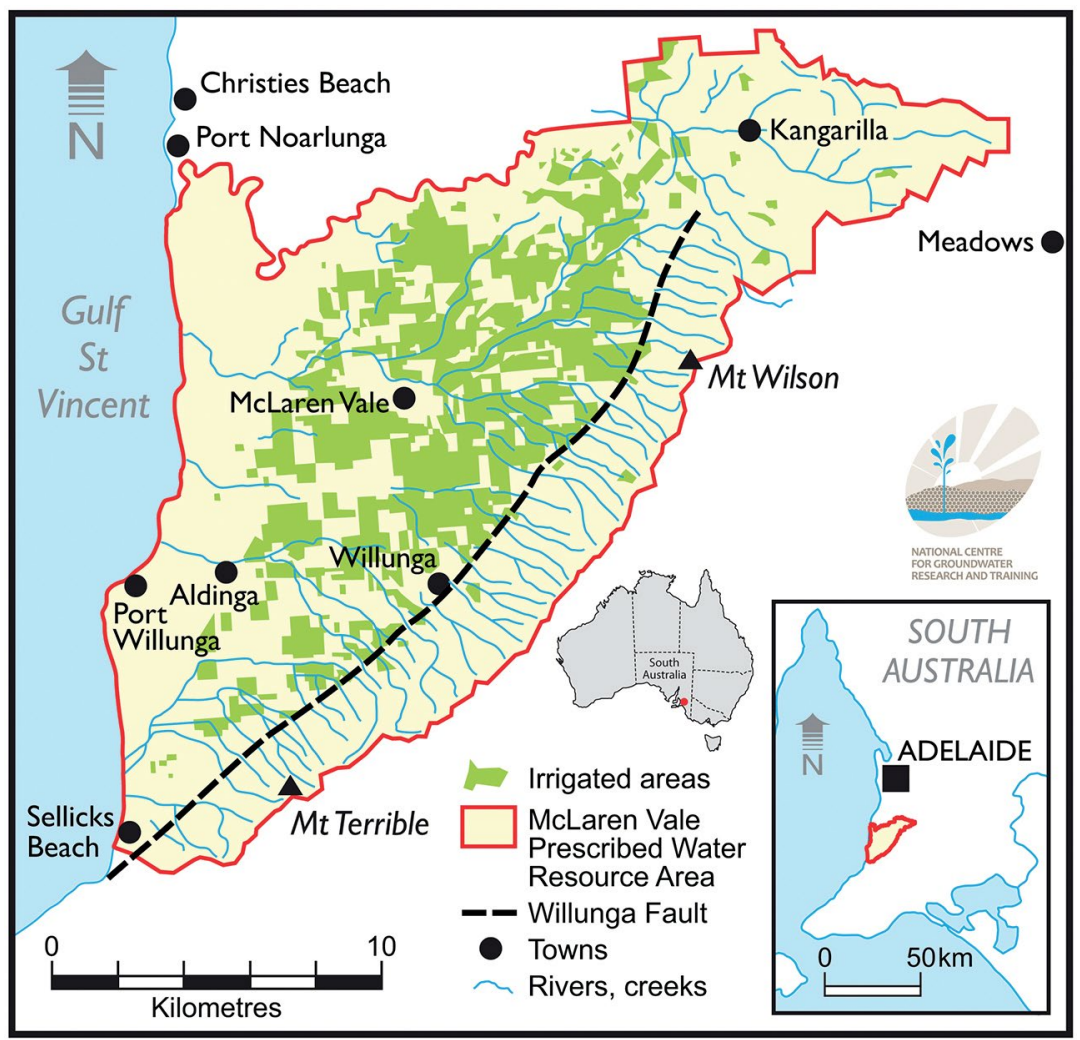

Figure 11.1: Willunga Basin - a geographic area, the majority of which was in the District Council of Willunga prior to 1997, and subsequently Onkaparinga Council, which amalgamated the councils of Happy Valley, Noarlunga and Willunga

Source: Harrington and Cook (2012: 11)

Aided by the Building Better Cities program funding (1991-96), established under the federal government of Paul Keating, the Willunga Council entered into a memorandum of understanding with the state planning minister in 1994 to undertake a strategic-planning process for the wider Willunga Basin area. Part of the process was to communicate and regularly inform the Adelaide Hills, Happy Valley and Noarlunga council planners of the progress of investigations concerning their areas within the Willunga Basin. 
Accepting that large parcels of land along the coast had been purchased by the state's then Urban Land Trust for future housing development, Willunga Council's strategic-planning process supported the McHarg (1969) planning approach ${ }^{4}$ and sought to identify an urban form along the coastal area with reference to land capability (PAS 1993), water sustainability (Cresswell 1994) and landscape values (Woodhead Firth Lee 1994). To this end, the council commissioned a land-capability assessment that extensively mapped the soils, climate, rainfall and groundwater in order to review the future of the Willunga Basin.

Investigations also included an economic study of the Willunga Basin, a landscape values analysis and an urban-form and water-resources study. As the water resource was considered a key planning issue of the process, each consultant team undertaking the urban-form, economic and waterresources studies worked collaboratively. Findings of the investigations established:

- potential for small-scale value-adding industries and enterprises aided by the establishment of economic incubators while conserving suitable land for viticulture and horticulture

- there was ample water from natural rainfall for horticulture, but winter storage and retention needed to be achieved possibly through groundwater injection and utilisation of treated waste water

- urban development to be contained along the coastal area in the form of high-density 'nodal' villages serviced by a dual reticulation - noncontact water being supplied by sewage treatment plants servicing each village in order to minimise impacts on the marine environment and manage water sustainably

- land-based disposal of treated water from waste treatment plants.

The outcome of the strategic-planning process was the completion of a Willunga Basin planning strategy accompanied by a budgeted five-year plan, reviewable each year. During the preparation of the strategic plan, constituent neighbouring councils of Happy Valley, Adelaide Hills and Noarlunga were consulted.

4 McHarg criticised a 'cookie cutter' approach to postwar suburban subdivisions and espoused a philosophy of landscape analysis so that new development could respond to landscape values through design approaches based on a comprehensive analysis of geology, typography, weather, landscape values and soil profiles. He worked and taught primarily in the United States. 
Consecutively, a plan amendment report was prepared to establish a District Council of Willunga Interim Structure Plan, which broadly identified a rural enterprise/conservation zone east of the Main South Road and a historic Port Willunga/Aldinga policy area within an overall coastal area west of Main South Road that was designated for future investigations into the recommended urban form.

Amalgamation of the then Happy Valley, Noarlunga and Willunga councils to form the City of Onkaparinga in 1997 resulted in the Willunga Basin strategic plan not being implemented. ${ }^{5}$

Building on the development of the Willunga Basin Strategic Plan pertaining to the southern portion of the Onkaparinga Catchment Water Management Board's area, the board sought to bring the land use-planning and catchment-planning systems into synchronicity across a wider region, which was enabled by the provisions of the Water Resources Act relating to catchment planning from 1998-2005. This was facilitated by the water reform process and this new legislation.

\section{A new legislative context}

\section{The national water reform agenda and the South Australian Water Resources Act 1997}

In the mid-late 1990s, the process of water-resource management change in South Australia was driven by the Council of Australian Governments (COAG) national water reform agenda (COAG 1994) and the reforms agreed to under the agenda by each Australian state were to provide an integrated, total catchment approach to water-resource management throughout the country. Funding by the federal system has favoured

5 Ongoing community pressure concerning the protection of rural land and water management, however, ultimately resulted in separate legislation to retain the rural character of McLaren Vale in the south, and the Barossa Valley north of metropolitan Adelaide in 2012 via the Character Preservation (McLaren Vale) Act 2012 and the Character Preservation (Barossa Valley) Act 2012. Ostrom (2008) emphasises the importance of community actions in the model of polycentric governance. In this case, organised community lobbying led to the drafting of the 2012 Act which maintained rural land and water resources capable of future food production close to the city - a major objective for sustainability first identified in the Willunga Planning Strategy of 1997 . The role of local community groups seeking greater assurance of the retention of rural land within the Willunga Basin exemplifies the concept of local advocacy in sustainable water and land uses. 
regions and been linked to ongoing reforms by each state. The water resources legislation established catchment water management boards, with a dual responsibility to prepare and implement a catchment water management plan and a water allocation plan for prescribed areas, which the Onkaparinga Catchment Water Management Board (OCWMB) undertook in 1999 and 2000 (see OCWMB 2000a; 2000b). The catchment boards were statutory bodies of the state government responsible for regional catchment scale management.

The area for which the OCWMB was responsible covers 920 square kilometres, partly within the Adelaide Hills Council, the cities of Marion and Onkaparinga, and the District Councils of Mount Barker and Yankalilla (Figure 11.2).

The McLaren Vale prescribed wells area is within the catchment, as well as a number of watercourses. Apart from the Onkaparinga River, all the watercourses have ephemeral flows within the catchment area (OCWMB 2000a).

Under s 92(7) of the Water Resources Act, the catchment water management plans were required to be in keeping with the following South Australian state legislation:

- Coast Protection Act 1972

- Development Act 1993

- Environment Protection Act 1993

- National Parks and Wildlife Act 1972

- Soil Conservation and Land Care Act 1989

- Native Vegetation Act 1991

- any other guideline, plans or policies as prescribed by regulation.

Importantly, the primary legislation in South Australia governing land-use planning, the Development Act 1993 and Regulations, and the then Water Resources Act 1997, made reference to each other in regard to consistency of respective state- and local-level plans. 


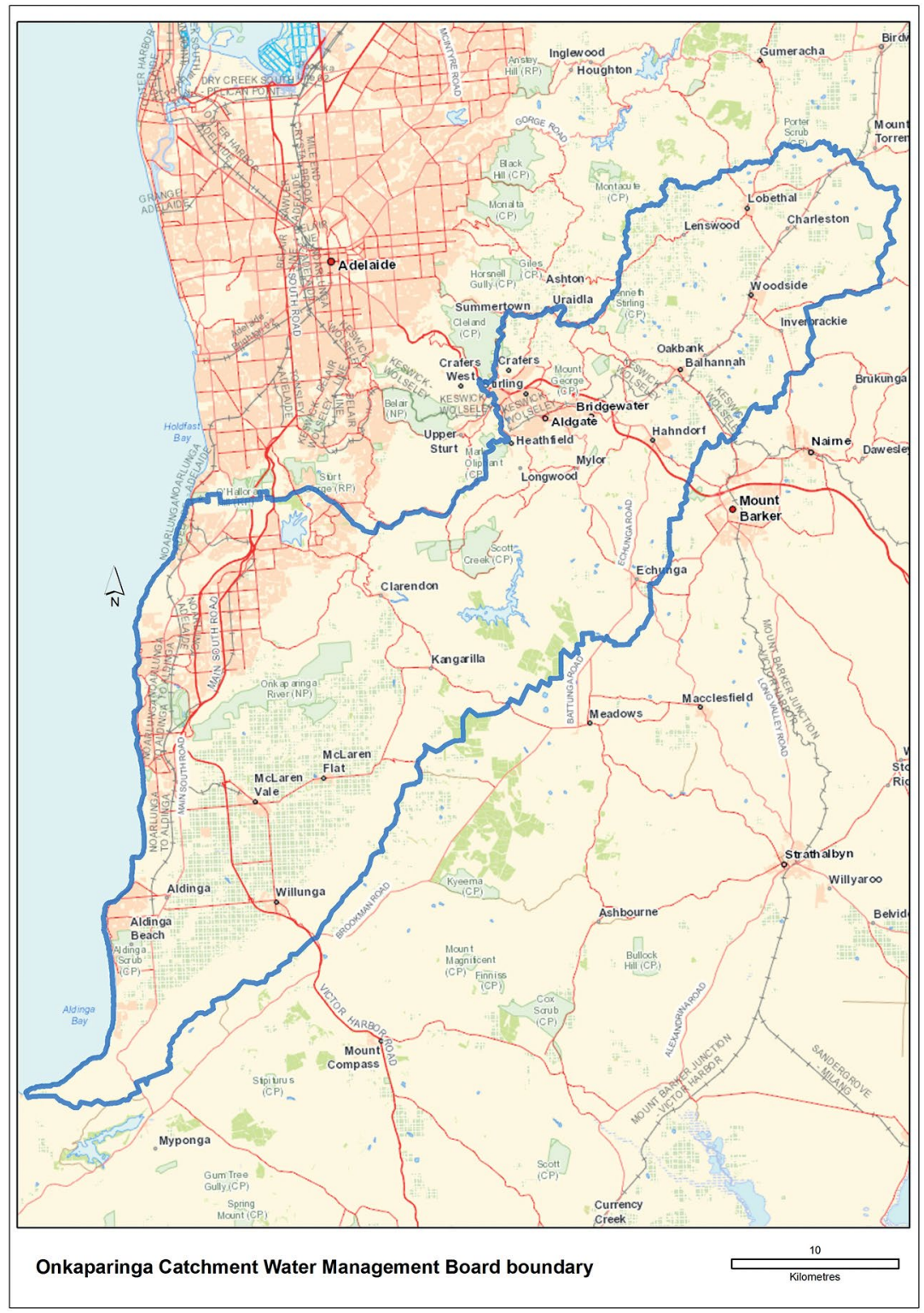

Figure 11.2: The Onkaparinga Catchment Water Management Board Area - showing council boundaries

Source: OCWMB (2000a: 10) 
The Onkaparinga Catchment Water Management Plan (Catchment Plan) (OCWMB 2000a) was in keeping with all of the above legislation. It was deemed by the OCWMB, however, that the development plans of constituent local councils - the primary tool of land-use planning under the Development Act - could be amended to better achieve the objectives contained in the Catchment Plan. The 'joined up legislation' meant one of two things at the time: first, the Catchment Plan and/or its implementation would be constrained by a number of policies that differed within the development plans of the five local councils; second, a catchment board could seek to utilise policies of a catchment plan as a trigger to amend the relevant development plans to meet the aim of achieving integration between the key policy documents relevant to the five councils and the state government by planning processes outlined in the water resource legislation. This second option would meet the aim of integrating key policy documents and legislation relating to land-use planning and water resources. The opportunity provided by the Water Resources Act up until the commencement in 2004 of the Natural Resources Management $A c t^{6}$ actively sought integration at a legislative level between the Development and Water Resources Acts.

\section{The players}

Federal, state and local governments were involved as a consequence of COAG's national water reform agenda and agreed reform. Local councils within catchment areas became key players in the reform process because of their responsibility for public spaces and obligations under the Development Act 1993. Under the Development Act, development plans provide a framework for managing new 'development', namely any change in land use, land division, the construction of dams and the location and design of new buildings or alteration of existing buildings, all of which impacted upon water catchment management to some degree.

6 The Water Resources Act 1997 was replaced by the Natural Resources Management Act 2004, which brought together legislation relating to water resources, soil conservation, pest plant and animal control. This reform replaced the catchment boards, soil conservation boards and animal and plant control boards with NRM boards. The geographic reach dealt with a regionally based area rather than catchment-based areas, incidentally changing the dynamics, nature and capacity of community engagement by the replacement body. It is of note that, when the provisions of the Water Resources Act were carried over to the Natural Resources Management Act, almost all provisions were transferred; however, the provision to enable catchment boards to change constituent council's development plans was omitted. 
At the state level, Planning SA was the key state government department reporting to the planning minister and in charge of residential and industrial development (e.g. Planning SA 1998, 1999). In relation to catchment management, there were several structural and administrative iterations of the Department of Environment and Heritage/Natural Resources and Department of Water reporting to the minister for the environment and/or water on matters relating to coastal areas, native vegetation, biodiversity and/or water resources management. In addition, other closely related agencies included the Environment Protection Authority (EPA), responsible for pollution prevention and management, and Primary Industries SA, responsible for sustainable agriculture. The catchment boards reported to the minister for environment and natural resources and, subsequently, the newly designated minister for water resources. The OCWMB area encompassed primary water catchments supplying metropolitan Adelaide.

The five constituent councils within the OCWMB boundary were geographically varied, ranging from urban to rural production and from hills to coast. Onkaparinga is the largest urban council in the Adelaide metropolitan area, resulting from the amalgamation of Happy Valley, Willunga and Noarlunga Councils, as outlined above.

\section{The Development Act and Water Resources Act planning processes}

At the state level, the peak planning documents are the State Planning Strategy (South Australian Government 2000), which is required under the Development Act, and State Water Resources Plan (South Australian Government 1999), required under the Water Resources Act. ${ }^{7}$ Nested within the State Planning Strategy and State Water Resources Plan respectively are local council development plans and catchment water management plans. All amendments to council and minister-initiated development plans within the council areas must be consistent with the State Planning Strategy. ${ }^{8}$ Plan amendments are made via a series of steps

7 The Water Resources Act established catchment water management boards. The six South Australian catchment boards were Northern Adelaide and Barossa Catchment Water Management Board, Onkaparinga Catchment Water Management Board, Patawalonga Catchment Water Management Board, River Murray Catchment Water Management Board, South East Catchment Water Management Board and the Torrens Catchment Water Management Board.

8 Development Act (SA) 1993. 
that generally take between three to five years to progress to endorsement by the state government. During the negotiated process of amendment, broad-based community consultation is required, including with state agencies. Section 30 of the Development Act requires a review of council development plans every three to five years. The planning minister may also amend development plans, consistent with the State Planning Strategy.

Similarly, the OCWMB was responsible for providing and reviewing a rolling five-year catchment water management plan to guide waterresource management within its area. The first Onkaparinga Catchment Plan was adopted by the then minister for water resources on 1 December 2000. The relationship between the two pieces of legislation and plans are depicted in Figure 11.3.

NRM Act 2004

Underpinning objective(s)

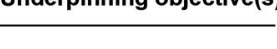

Strategic policies

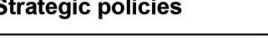

Instruments of control

Natural resources management
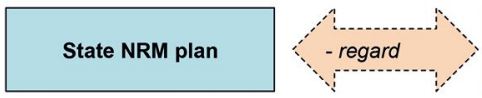

State Planning Strategy
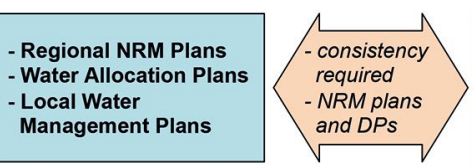

Development Plans

Social, Environmental \& Economic

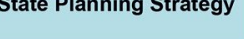

\section{Development Act 1993}

Water affecting activities (other than 'development')

- Water allocations $I$

transfers

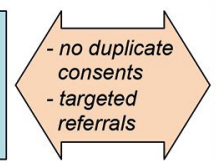

- New 'development' (land uses \& building), including some water affecting activities

Figure 11.3: The relationship between the Development Act, Water Resources Act and state and local government roles

Source: Author's construction in conjunction with R. Teague, Planning SA, Department of Transport and Urban Planning (Bellette 2004)

In looking at the sustainable use of water as part of investigations for the Catchment Plan, the OCWMB estimated that the available water resources within the board's area comprise urban and rural surface flows $(105,000 \mathrm{ML}$ per annum (ML/a)), groundwater (18,000 ML/a) and effluents from wastewater treatment plants $(12,400 \mathrm{ML} / \mathrm{a})$. Supplementing this included imported water from the River Murray via the Onkaparinga 
pipeline (24.000 ML/a) and from Myponga Reservoir. Of the 160,000 $\mathrm{ML} / \mathrm{a}$ available water, about one-third is used within the catchment area, with 47,500 ML exported to Adelaide and about 35 per cent out to the marine environment. Beginning with this equation, sustainable water use would involve:

1. Increasing the use of stormwater and wastewaters which are presently unused and which have an undesirable impact on their environments, resulting from or related to their non-use

2. Using waters to augment or replace waters taken from existing sources, in so far as investigations show the economic practicality and relative long term benefits of so doing

3. Increasing the efficiency of using existing and new water sources and systems

4. Identifying more clearly the water needs of ecosystems (environmental flows etc.) and allocating water of adequate quantity and quality to meet those needs

5. Working with other Boards and agencies to reduce dependence of Adelaide on River Murray water and any associated, non-essential diversion of this water into and out of the catchment in the light of findings on the feasibility and benefits of using, and / or increasing, the efficiency of using existing and new water sources and systems

6. Aquifer storage and recovery opportunities (OCWMB 2000a).

Table 4.1 of the Catchment Plan (OCWMB 2000a) identifies where planning is relevant to key issues:

1. Limited use of water sensitive design, and land management. The reasons for this include the fact that the housing industry is slow to provide smart new development, the low use of stormwater and lack of integrated design. It is desirable to incorporate policies into Development Plans to encourage water sensitive design at household, community and regional levels while acknowledging that local councils in the process of managing the public environment can establish best practice in stormwater treatment, including the design of public reserves, streets and drainage systems.

2. Minimum standards for housing development are desirable, including on-site rainwater storage and re-use, and the provision of dual systems where non-contact water can be provided from rainwater collection (e.g. plumbing into laundry and toilet directly from a rainwater tank) as part of a minimum standard for development. Ideally, new housing 
areas should be required to incorporate local stormwater treatment systems and a set of dual reticulation pipes required for new homes to further reduce the demand for potable water.

3. The impact of dams on surface water flows in the McLaren Vale Prescribed Wells Area and the Mt Lofty Ranges Watershed and policies for development of new dams that address the need to maintain low flows during low rainfall periods for maintenance of watercourse environmental health.

4. Managing Growth - new urban infrastructure targeting land and industrial water re-use options, with an informed urban population and behavioural changes to less waste, improved biodiversity, enhanced sense of relevance and commitment to sustainable water use, and increased awareness of water 'processes'.

\section{Integrating catchment management within the planning system}

In the closing years of the 1990s there were two options for the OCWMB to integrate policies from the Catchment Plan with local government development plans:

1. The Water Resources Acts 96 allowed the state water resources minister, in consultation with the state planning minister, to identify the need for an amendment of a development plan of a constituent council/s via the catchment plans. The Minister for Planning must also approve the Plan Amendment Report, i.e. consensus between both ministers is required.

2. The Development Act allows councils, authorised by the state planning minister, to amend Council Development Plans.

In aiming to have all development plans of councils within the catchment support the catchment water management plan, the OCWMB did not request the minister for water resources to authorise amendment of the relevant development plans. For a newly formed board, this option was deemed unlikely to be well received by councils. Instead, the board aimed to work with their councils collaboratively by funding and coordinating an integrated development plan amendment on behalf of councils for approval by the planning minister (Bellette 2001). 
Moreover, one of the stated goals of the OCWMB was to integrate resource management through coordinated policies 'and effective partnerships between stakeholders' (OCWMB 2000: v).

The OCWMB then began negotiation with councils, with a view to undertaking, on behalf of councils, the preparation of a catchment-wide development plan amendment based upon a review of each development plan, for approval of the planning minister. The development plans are council-based, which meant each development plan had to be separately reviewed as part of an integrated development plan amendment. Afterwards, the board approached the individual councils and obtained their agreement to the amendment of each council plan to incorporate catchment management principles. The OCWMB appointed a consultant planner to firstly prepare a standard draft set of objectives and principles and review each development plan within the catchment. The exercise was aimed at encouraging development mindful of catchment care from 'site to sea'.

The first phase of obtaining the agreement of local councils within the catchment to participate was followed by formulating a statement of intent (SOI) to which the participating councils jointly signed for ministerial consent to proceed. Once the planning minister's support was granted, an intensive process of reviewing each existing development plan to crosscheck existing policies in the individual council plans that impinged on water management processes was undertaken, incorporating consultation with council planners on a regular basis.

The OCWMB endorsed draft development plan amendment provisions to address minimisation of erosion, siltation and urban design standards conducive to sustainable water use. As a draft, the Catchment Plan Amendment Report (Catchment PAR) addressed issues such as requirements for water-sensitive design for new development and encouraged aquifer storage recovery of treated wastewater and stormwater.

A steering committee comprising senior planners of each council, planner representatives from Planning SA, the Water Resources Department and OCWMB members was formed with oversight of the Catchment PAR process. Each stage of the Catchment PAR process, including the SOI that outlines the scope of the proposed Catchment PAR, was signed off by all councils, and subsequently the state planning minister. 
In the process, it was possible to position water catchment issues in a proactive manner into the 'mainstream' land-use planning system, rather than the catchment policies being outside this framework and therefore in a reactive position (see also Smith and Iwanicki 2004). It was believed by the OCWMB that, as much as possible, catchment management issues should be internalised into the daily management framework of state and local governance in recognition of water as a basic need (Bellette 2000).

In addition to the Development Act activities, the OCWMB utilised provisions under the Native Vegetation Act 1991 to move to incorporate a refund of the Division 2 levy (via s 140 of the Act) ${ }^{9}$ into its Catchment Plan for landholders holding a Native Vegetation Heritage Agreement over their land. The agreements are made under the Native Vegetation Act and require property owners to maintain and manage native vegetation in perpetuity, in return for in-kind assistance from the Department of Environment and Heritage. In doing so, the board recognised that the preferred land use in a catchment where water quality is the primary objective is undisturbed native vegetation and this sends positive reinforcing messages to the community about the value of good catchment management (Bellette 2001).

\section{What and who were driving the negotiations?}

The aim of the board was to ensure that each development plan contained policies that enabled those in the catchment water management plan.

The project was initiated by the OCWMB. The entry point to the process was informal approaches by the OCWMB general manager to the heads of planning from each of the five local government councils to discuss the likely interest of each council at large, including elected members. Upon receiving positive feedback, the OCWMB developed a written proposal and presented this to each council. Each council then agreed that the OCWMB would engage a consultant to develop a catchment-wide plan

9 The Water Resources Act Division 2 s 135 allows for councils to contribute to catchment water management boards whereby catchment water management plans specify an amount to be contributed by each council based on their proportionate share of the catchment. This levy is passed on by councils to landholders under s 138 . Section 140 allows catchment boards to refund levies paid by landholders who undertake land- or water-management practices designed to conserve water or maintain or improve water quality or provide other benefits. 
amendment report on their collective behalf covering each of the five councils to ensure consistency of policies across the councils that enabled relevant catchment plan policies listed above.

The process from July 2000 to December 2005 involved the following legislative steps required by the then current provisions of the Development Act for amending a development plan. The SOI was endorsed by councils.

1. SOI was submitted to Planning SA for ministerial approval. The SOI envisaged a timeframe for the minister to consider the amendments to the development plan(s) for adoption in November 2002.

2. The SOI was approved by the minister for planning.

3. Councils were provided with draft plan amendments for endorsement.

4. The draft for consultation was agreed to by all councils (except Yankalilla Council). At this time Yankalilla withdrew, as the proportion of the DC Yankalilla within the boundaries of the OCWMB was considered insignificant.

5. Draft plan amendments were submitted to Planning SA for ministerial approval to commence consultation. Ministerial approval was granted.

6. Consultation on the draft OCWMB PAR took place, with two public hearings.

7. Submissions were summarised and addressed in a report for OCWMB.

8. The final plan was presented to councils for endorsement. The cities of Onkaparinga, Marion and Mt Barker supported endorsement.

9. Planning SA was requested to endorse amendment for Onkaparinga, Marion and Mt Barker.

10. The EPA and the Adelaide Hills Council had raised concerns.

11. Concerns were addressed - development plans for these councils were then submitted to Planning SA and received ministerial authorisation.

Different geographically grounded issues between councils resulted in some councils accepting the water-sensitive planning policies more readily than others (See Figure 11.4). 

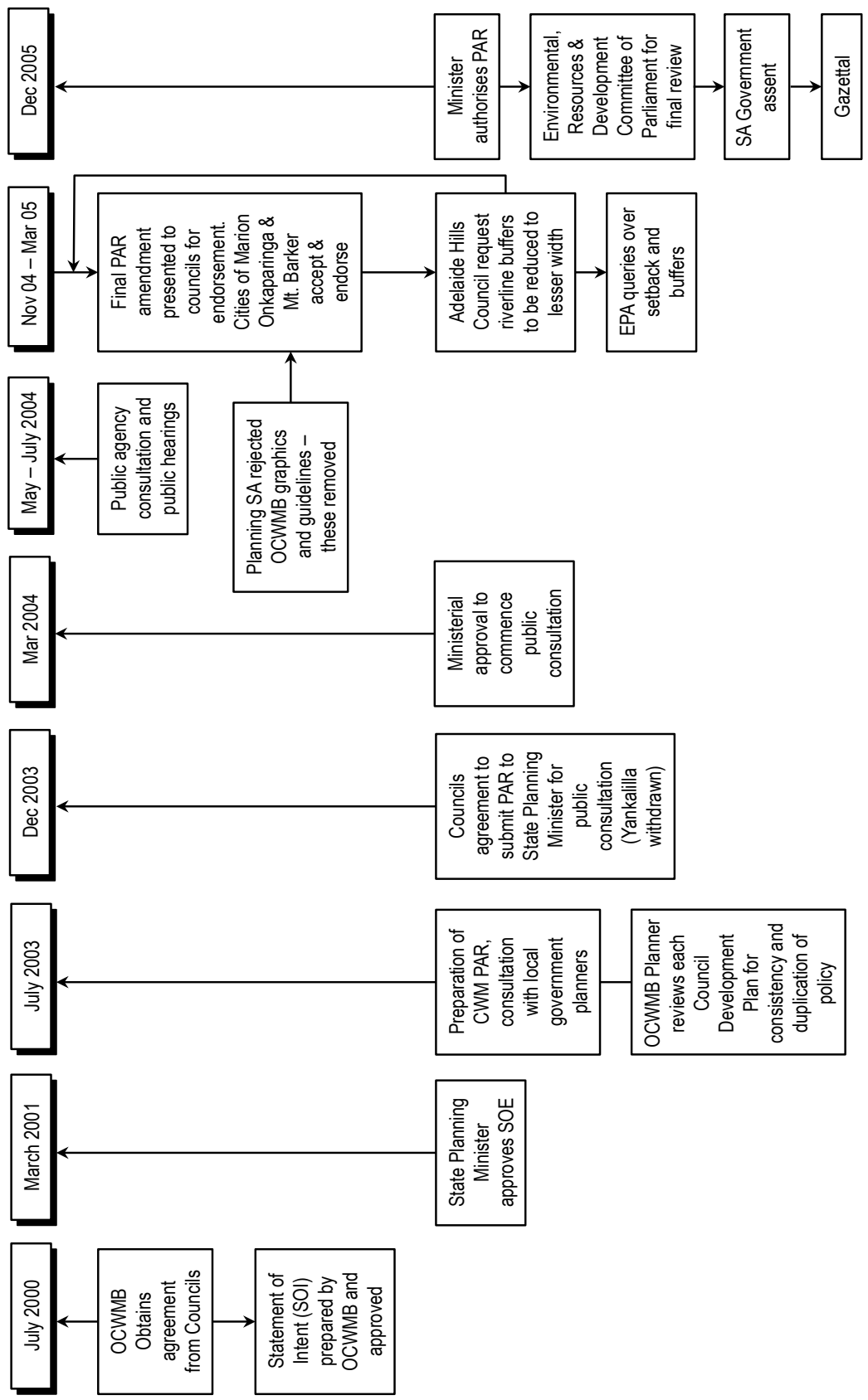

Figure 11.4: Multi-level governance reform - the development plan amendment

Source: Iris Iwanicki 


\section{Matters raised during the process}

The predominantly rural Adelaide Hills Council requested buffers to be no greater than 5 metres because of the perceived economic loss due to land being removed from production via wider buffers. The state EPA, however, indicated it wanted buffer provisions of 50 metres to be consistent with existing setback requirements, which dealt with septic tank installations near watercourses. The provisions were changed by the OCWMB to meet the requirements of the Adelaide Hills Council. The OCWMB also clarified with the EPA the nature of buffers as opposed to setback distances.

Planning SA was supportive of the amendment but, since the commencement of the catchment PAR, they started developing modular topic-based templates of policy principles in order to provide consistency across council development plans within the state. While the Catchment Plan review process sought to provide relevant guidelines and examples in one legislative document, Planning SA considered that much of the content of the amendment was more suitable for a guideline than a PAR, including the diagrams and design techniques developed. The OCWMB was concerned, however, that without incorporation in the development plan the information would be difficult to require from applicants. Ultimately, Planning SA endorsed the amendment following the excision of the graphic material originally provided.

Despite the various issues raised by different agencies and levels of government, and given the complexity of changing legislation, local government structures and state agency approaches, the process of integrating development planning with catchment planning was enabled by a number of factors discussed in the following sections.

\section{The importance of individuals}

The OCWMB and staff had a pre-existing relationship with the five councils and staff and worked closely with them on the drafting of the Catchment Plan. Councils, therefore, had a level of ownership of the Catchment Plan. Furthermore, part of the implementation of the plan was to ensure consistency with each council's development plan; hence, they already had a level of 'buy in' to the Catchment PAR. 
In addition, representation of the two major councils within the catchment on the OCWMB sustained earlier commitment to the process. The two councils collectively comprised the majority of the board's area: one board member was an elected member of the Adelaide Hills Council, and one member was the CEO of the Onkaparinga City Council. Although both the Development Act and Water Resources Act had provisions for ensuring that catchment and development plans were consistent, no Catchment Board at the time had considered or triggered the process through either Act.

The integration process was initiated by the general manager and subsequently followed through by the board's land-use planner, who could both see the significance of the opportunities, importantly to the benefit of both land-use planning and catchment management. The general manager had worked in both land-use planning and natural resource management and environment protection, and promoted communication and integration across the disciplines and relevant government bodies.

The OCWMB played a role by recognising the significance of land-use planning to enable some aspects of the board's Catchment Plan, and therefore made a significant investment to employ a land-use planner (the only catchment board in South Australia to do so). The catchment planner was previously employed by the Adelaide Hills Council, one of the five councils involved in the PAR.

The planning consultant chosen to undertake the joint five-council PAR was previously the environmental services manager and strategic planner in the former Willunga Council, now amalgamated into the Onkaparinga Council. One of the significant enablers in the PAR process was the work history, local knowledge and networks provided by these two planners.

In summary, the project was driven by three people - initially the general manager of the OCWMB, then the OCWMB land-use planner and the planning consultant.

\section{Timelines and resources}

The total length of time from initial floating of the concept to PAR approval was in the order of five to six years, as shown in Figure 11.4. Issues raised by different participants at different stages of the amendment process involved negotiation prior to final drafting, but at no stage was the outcome at risk. 


\section{Has the process succeeded and why?}

The process of incorporating catchment planning and land-use development planning policies was successful, given the commitment and resources from the board staff and consultant planner and significant in-kind contribution from the five constituent councils. In addition, the process was aided by:

- having representatives of the Adelaide Hills Council (ex-mayor and then current councillor) and the CEO of the Onkaparinga Council as board members, who were supportive of the catchment program

- the board recognising the significance of land-use planning to enable some aspects of the OCWMB's catchment plan and therefore employing a land-use planner

- the continuity of commitment and drive of the three employees responsible for the various stages of the Catchment PAR.

For its part, the OCWMB pursued integration of policies by taking responsibility for:

- funding the PAR so the review and amendment process of council development plans were cost-free to local government (councils, apart from in-kind contributions through participating in discussions on the content and approach to the PAR, did not have to undertake the review directly)

- taking responsibility for shepherding the passage of the PAR through state government processes, again, a cost-free process for local councils

- not proceeding at any stage of the amendment unless first obtaining approval from each council

- establishing strong community links and support for the project

- acting as a facilitator between state and local government

- having an already established relationship between the OCWMB and constituent councils through engagement on drafting the catchment water management plan and subsequently funding on-ground catchment projects within councils.

Among the observations and lessons learnt from this MLG case study was the frequent complaint by developers and the public that development plans provide little guidance for applicants. During the process, board planners discussed the need for more guidance, including illustrative 
examples to provide clarity of policy. The desirability of achieving watersensitive design in all new development provided a basis for drafting illustrative principles that addressed the following:

- site management - prior to, and during, construction of buildings, sites to be managed in order to prevent excess erosion and siltation following clearance and management of litter/waste during construction

- building design, car parks

- stormwater systems

- on-site rainwater retention and re-use.

The illustrative guidelines were subsequently discarded when it was clear that not all councils concerned, nor the state, were supportive of this approach. Similarly, the maximisation of water re-use through planning policies was also approached with caution by government. It appears that, despite the rhetoric of catchment management, implementation is difficult and slow. The use of topic-based modules with standardised text and the requirements for consistency in preparing amendments did not encourage creativity in the drafting of development plans.

Some of the reasons for success or otherwise are based on the process and the governance level at which amendments to planning policies are attempted. It is clear that policies alone will not result in change and need to be accompanied by extensive education of practitioners on desirable design and management for water sustainability. As there was limited understanding amongst council staff and elected members regarding catchment management, there is a need to provide more education on the consequence of actions, particularly around land-use planning. Also, catchment management, while a priority for the OCWMB, was not necessarily a priority for councils and therefore difficult to get on council agendas. Staff shuffling throughout councils and Planning SA meant that experienced council staff were lost from the process. At a state level, ongoing review of the planning system focused on simplifying development plans and thereby improving processing times and expediting development. The specific nature of zoning for individual councils in response to local conditions is consequently often problematic to development plan reform.

Education of the planning profession tends to focus on development. In a broader sense, planners generally lack the capacity to integrate and apply NRM policies. Ongoing professional development for planners should involve: 
- an understanding of the resource implications of urban growth

- an understanding of the usefulness of on-site rainwater collection and incentives to the building industry/building owners to incorporate rainwater tanks of adequate capacity in the planning and design of buildings

- incentives and obligations placed upon the design and building industries to begin to provide the consumer with water-sensitive design choices.

For councils/state levels, adoption of the following (which have since become more commonly applied) should involve:

- best practice in council's management of public spaces and stormwater systems

- insistence that new developments score a total of points for environmentally and economically sustainable features in the design of new buildings before being granted development approval

- linking with local suppliers/industries to promote products that conserve water in the household

- incentives for infrastructure systems to provide for water of non-potable quality for watering gardens, flushing toilets and other acceptable uses

- a state campaign of promoting water-sensitive design through publicity, legislation and accreditation procedures to provide consumers with better housing/building choices

- state encouragement and support for the revival of state and local Agenda 21 planning that addresses social, economic and environmental aspects of the community and their environment

- follow-up inspections during construction to ensure that site management systems are being implemented.

\section{Conclusion}

The OCWMB was the first catchment board in South Australia to undertake a process of integration of its Catchment Plan with constituent council development plans. The Northern Adelaide Barossa Catchment Water Management Board later followed the process. 
Given the above lessons and observations, the success of the process demonstrated that having key 'champions' who had the persistence to collectively steer what was a lengthy process through the many changes in policy and government structures at multi-government levels was vital. The success was also partly achieved by the fact that the catchment boards were associated with specific communities within a defined catchment area, focused on a specific issue (water) and facilitated involvement of many different community groups. Community awareness of the issues involved in catchment care was well established when the reviewed PAR was put on public exhibition. Much of that awareness was encouraged by a well-focused program of public involvement, specifically in catchment issues and reinforcing the shared nature of water resources throughout a catchment area in terms of sustainable water use, water-based biodiversity, and pollution impacts downstream and upon the marine environment. With the larger geographic areas covered by respective NRM boards, the same level of community involvement and engagement does not appear to have been achieved.

The specific legislative reference to linking the development plan and catchment planning processes at regional level was lost with the amendment of the Water Resources Act when it became part of a broader piece of legislation via the Natural Resources Management Act. ${ }^{10}$ Although a planning pathway for synchronising regional NRM plans and council development plans remains possible via the Development Act, ${ }^{11}$ the emphasis within the Natural Resource Management Act and Development Act is on gaining concurrence with state-level plans, rather than at both the state and local/catchment levels.

In conclusion, certainly the intent of the relevant legislation was to achieve MLG, both horizontally between the state government portfolios and across local governments located geographically within catchments, and vertically between local and state governments. The changes to state government administrative structures and methods for standardising

10 Nevertheless, s 74(4) of the (current) Natural Resources Management Act 2004 does require the state NRM plan to take into account the provisions of the Planning Strategy and may identify changes (if any) considered by the NRM Council to be desirable to the State Planning Strategy. The reciprocal provisions in the Development Act, however, although similar in intent, are not so specific. Section 22(3) requires that the Planning Strategy may incorporate documents, plans, policy statements, proposals and other material designed to facilitate strategic planning and coordinated action on a state-wide, regional or local level.

11 In fact, as outlined above, this was the pathway chosen by the OCWMB for the catchment-wide development plan amendment via the Catchment PAR. 
planning guidelines during the MLG integration process undertaken by the OCWMB, however, made the process undertaken to achieve this very protracted. Ultimately, the success achieved in integration across and within levels of government was short lived due to the amalgamation of boards under the Natural Resources Management Act 2004. To date, under the NRM regime, application of the processes available to integrate landuse planning and natural resources planning has not been undertaken comprehensively at state level, nor at the regional level.

The exercise and lessons could consequently be seen as somewhat historical but, nevertheless, instructive as a demonstration of the innovation potential arising from integrated MLG planning systems.

\section{References}

Bellette, K. (2000). The Water Resources Act 1997 - A Quantum Leap in Funding for Sustainability. Paper presented to the Water Law Seminar. Hydrological Society of SA and the National Environmental Law Society (SA), October 2000, Adelaide.

- (2001). Legislation and Policy - One Sixth of the Equation for Sustainable Water Resource Management. Paper presented to the Third Australasian Natural Resources Law and Policy Conference (focus on water), Adelaide.

- (2004). The Role of Planning in Advocating the Use of Alternative Water sources in the Urban Environment. Presentation at the Enviro04 Conference and Exhibition, March 2004, Sydney.

COAG (1994). Council of Australian Governments' Water Reform Strategic Framework. 25 February 1994, Council of Australian Governments Communiqué, Hobart, www.environment.gov.au/ system/files/resources/6caa5879-8ebc-46ab-8f97-4219b8ffdd98/files/ policyframework.pdf, [Accessed: 22/12/2014].

Cresswell, D.J. (1994). Willunga Basin Integrated Water Resources Study. Department of Housing and Urban Development/Department of Environment and Natural Resources, DC of Willunga, South Australia. 
Harrington, N. \& Cook, P. (2012). Willunga Research Update, October 2012. National Centre for Groundwater Research and Training, Adelaide.

Hooghe, L. \& Marks, G. (2001). Types of Multi-level Governance. European Integration online Papers (EIoP), 5(11), eiop.or.at/eiop/ pdf/2001-011.pdf [Accessed: 22/12/2014].

Iwanicki, I. (1994). Rural/Urban Fringe Planning in Adelaide, South Australia. Paper presented at the Global Forum, Manchester, England.

__. (1995). Seeking Sustainability in the Rural/Urban Fringe An Overview of the Willunga Basin. Paper presented at Portraits in Planning Conference. October 1995, Adelaide.

McHarg, I. (1969). Design with Nature. Garden City Press, NY.

OCWMB (2000a). Onkaparinga Catchment Water Management Plan. Onkaparinga Catchment Water Management Board, Adelaide.

- - (2000b). Water Allocation Plan, McLaren Vale Prescribed Wells Area. Government of South Australia, Adelaide.

Ostrom, E. (2008). Polycentric Systems as One Approach for Solving Collective-Action Problems, dlc.dlib.indiana.edu/dlc/bitstream/handle/ 10535/4417/W08-6_Ostrom_DLC.pdf [Accessed: 22/12/2014].

PAS (1993). Willunga Basin Land Capability Study-Final Report. Planning Advisory Services/Eco Management Services, South Australian Office of Planning and Urban Development and Willunga District Council, Adelaide.

Planning SA (1998). Planning Bulletin, Industrial Development. Adelaide.

__. (1999). Good Residential Design SA. Adelaide.

- _. (2004). Slide from a generic presentation on the State Planning Strategy. Department of Transport and Urban Planning. Adelaide.

PPK (2000a). Onkaparinga Catchment Water Management Plan Local Government and Development Plans. Technical Paper 3. PPK Environment and Infrastructure, Adelaide. 
- (2000b). Onkaparinga Catchment Water Management Plan - Land Capability and Land Use. Technical Paper 5. PPK Environment and Infrastructure, Adelaide.

Smith, S. \& Iwanicki, I. (2004). The Good, the Bad and the Ugly Integrating Catchment Management and Development Planning. In: Proceedings of 'WSUD 2004: Cities as Catchments' International Conference on Water Sensitive Urban Design. Engineers Australia, Barton, ACT, pp. 721-28.

South Australian Government (1993). Development Regulations. Adelaide, www.legislation.sa.gov.au/LZ/C/R/Development $\% 20$ Regulations\%201993.aspx

—_. (1999). State Water Plan. Adelaide.

- (2000). Planning Strategy for Metropolitan Adelaide. Department of Transport and Urban Planning, Adelaide.

Woodhead Firth Lee (1994). Willunga Basin Urban Form and Landscape Study. Deptartment of Housing and Urban Development, District Council of Willunga, South Australia. 
This text is taken from Multi-level Governance: Conceptual challenges and case studies from Australia, edited by Katherine A. Daniell and Adrian Kay, published 2017 by ANU Press, The Australian National University, Canberra, Australia.

dx.doi.org/10.22459/MG.11.2017.11 